\title{
PELAS BANDAS DE SANTO AMARO: MÚSICA, COLETIVIDADE E PERTENCIMENTO - ELEMENTOS PARA A CONSTRUÇÃO DE UMA IDENTIDADE
}

\section{BY SANTO AMARO BANDS: MUSIC, COLLECTIVITY AND BELONGING - ELEMENTS FOR THE CONSTRUCTION OF AN IDENTITY}

\author{
José de Carvalho Oliveira \\ Universidade de São Paulo \\ josedecarvalhosax@gmail.com
}

\section{Resumo}

A partir das relações que se estabelecem entre as tradicionais bandas de coreto e povo no que se refere à memória e ao coletivo, este trabalho busca apresentar interfaces entre música, coletividade e pertencimento como elementos para construção de uma identidade. Para este estudo, a partir de fontes iconográficas, utilizaremos como referência as bandas de música do antigo município de Santo Amaro - SP, incorporado à capital Paulista em 1935. No que diz respeito aos resquícios da herança cultural das bandas do antigo município, utilizaremos como base as atividades da atual Banda Municipal de Música da cidade de Embu das Artes - SP.

Palavras-chave: Identidade Cultural; Pertencimento; Bandas de Santo Amaro; Bandas de Música; Práticas Coletivas.

\section{Abstract}

Based on the relationships established between the traditional bandstands and the people with regard to memory and the collective, this work seeks to present the interfaces between music, collectivity and belonging as elements for building an identity. For this study, using iconographic sources, we will use as a reference the music bands from the old municipality of Santo Amaro - SP, incorporated in the capital of São Paulo in 1935. With regard to the remains of the cultural heritage of the 
bands from the old municipality, we will use as a base the activities of the current Municipal Music Band in the city of Embu das Artes - SP.

Keywords: Cultural Identity; Belonging; Santo Amaro Band; Music Bands; Collective Practices.

\section{Introdução}

Desprezada pela historiografia e às vésperas de completar quase 100 anos da incorporação de Santo Amaro como bairro da capital paulista, pesquisas recentes, no âmbito acadêmico, têm proporcionado avanços no tocante à história do antigo município de Santo Amaro, sobretudo os estudos de Peralta (2017 e 2019). Porém, apesar da representatividade do trabalho de Peralta, o levantamento bibliográfico realizado por esta pesquisa averiguou a ausência de uma maior cobertura historiográfica e acadêmica - dada a importância do município para os processos de urbanização e desenvolvimento da cidade de São Paulo.

Os reflexos do absentismo historiográfico reverberam também no que diz respeito às práticas culturais, ao espaço social e à arte coletiva, principalmente, no que se refere às bandas de música do antigo município. A partir dessas observações, transparece a compreensão de que o estudo realizado por este trabalho se mostraria muito maior do que apenas uma pesquisa historiográfica, já que seria necessário reconstruir parte da história perdida bem como edificar referências para melhor entendimento do contexto relacionados às práticas musicais, seus músicos, maestros e as relações intrínsecas entre banda e a comunidade santo-amarense.

Sobre as manifestações culturais em relação à música, partindo do pressuposto de que hoje Santo Amaro é um bairro da capital paulista, este trabalho fundamentou-se inicialmente na busca por dados a partir de órgãos oficiais como, por exemplo, o site da Prefeitura de São Paulo, que nos permitiu constatar a existência de poucas informações, porém muito significativas para o desenvolvimento desta pesquisa.

Entre os dados encontrados no site da Prefeitura de São Paulo, está a referência à fundação do Conservatório Musical de Santo Amaro no ano de 1931 e a confirmação da existência da Banda Musical 
de Santo Amaro. Essa confirmação se dá pela menção ao Largo do Rosário (atual Praça Floriano Peixoto, Figura 1) - onde se situavam a Cadeia Pública, também a Câmara Municipal (atual Casa de Cultura) e o "Coreto onde aconteciam as apresentações da Banda Musical de Santo Amaro'".

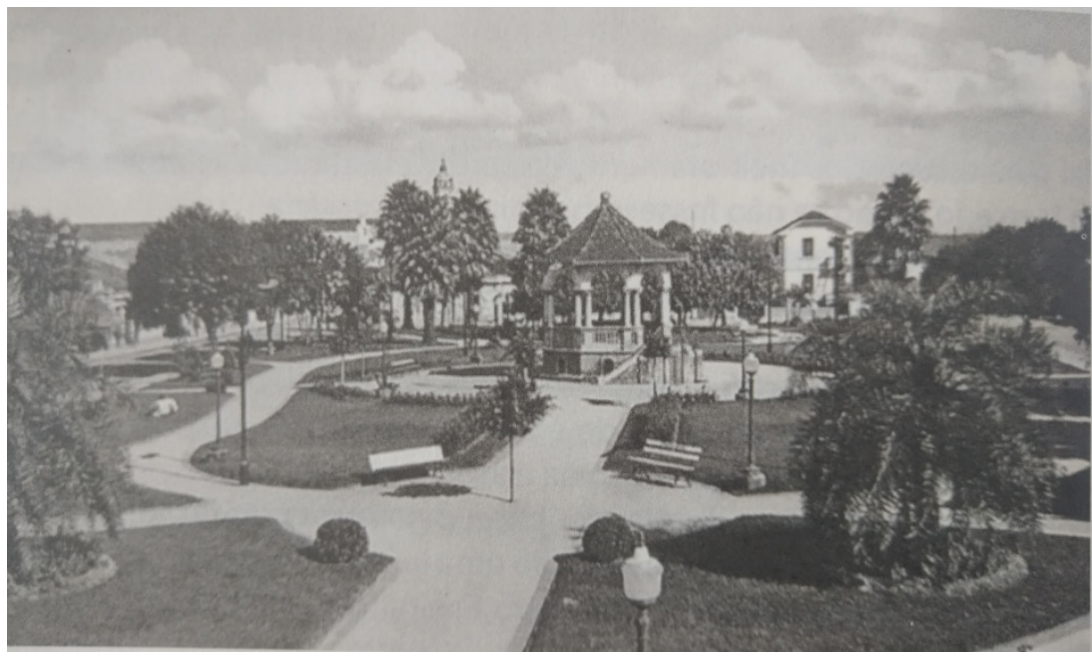

Figura 1. Largo do Rosário, ano de 1935. Atualmente denominado Praça Floriano Peixoto, situada no centro do bairro de Santo Amaro. Fonte: Arquivo pessoal de Monsenhor Jamil Nassif Adib (PERALTA, 20 17).

Com relação às interações entre a prática musical e o espaço social, abordaremos a música como elemento de conectividade nos processos coletivos que convergem para a construção de uma identidade. Sobre essa perspectiva, este estudo busca mostrar um quadro de trocas permanentes em que a prática musical reflete e expressa o espaço social em que ela está inserida, conferindo a esse espaço sentidos particulares.

Sobre a música, enquanto veículo de transmissão e aproximação presente nos diversos cenários da história humana notabilizam-se as

I https://www.prefeitura.sp.gov.br/cidade/secretarias/subprefeituras/santo_amaro/historico/ - Acessado em 04/01/2020

\section{8}


atividades das bandas de música na representação de ser, através do reconhecimento público, agentes de reunião e de interação entre as diferentes partes da população urbana (SANTIACO, 1998, p. 191).

Referente ao papel das bandas de música do antigo município de Santo Amaro e suas relações nos processos de construção da identidade santo-amarense, este estudo procurou fundamentar-se na análise da cidade por intermédio dos traços que os referidos grupos musicais nela deixaram.

Para este trabalho, no que se refere à música, coletividade e pertencimento, utilizaremos como referência os estudos de Cunha (2013). Com relação à banda de música e suas relações com a vida social urbana, como base, os estudos de Santiago (1998). Em referência às questões históricas relacionadas ao município de Santo Amaro, recorreremos aos estudos de Peralta (2017 e 2019), além de fontes iconográficas recolhidas em arquivos digitais, disponibilizados em plataformas oficiais ligadas à Prefeitura de São Paulo, jornais, revistas, redes sociais e blogs que tratam da memória de Santo Amaro.

\section{A cidade que virou bairro de São Paulo}

De acordo com o site da Prefeitura de São Paulo, logo após a fundação de São Paulo em 1554, os jesuítas foram distribuídos, sob as ordens do Padre Manuel da Nóbrega, na Capitania de São Vicente em três locais: São Vicente, São Paulo e Jeribatiba (atual bairro de Santo Amaro). Em 1686, no dia 14 de janeiro, a Capela Curada de Ibirapuera é elevada a Freguesia e, em 1833, no dia 6 de maio, acontece a primeira Assembleia da Câmara dos Vereadores do município de Santo Amaro.

A circunscrição de Santo Amaro era imensa. Entre os pontos mais centrais do município estavam as áreas do cemitério de Santo Amaro (atualmente o mais antigo da cidade de São Paulo em funcionamento) (PERALTA, 2019), Aeroporto de Congonhas e a Represa do Guarapiranga. A abrangência territorial contemplava desde o sul do Córrego da Traição (Avenida dos Bandeirantes) até a Serra do Mar, incluindo as áreas dos municípios de Itapecerica da Serra, Embu (hoje Embu das Artes), Embu-Guaçu, Taboão da Serra, São Lourenço da 
Serra e Juquitiba, emancipados em 1877 formando um único município, o de Itapecerica da Serra. Entretanto, no início da segunda metade do século XX, ocorre o desmembramento de Itapecerica da Serra, tornando esses municípios independentes na maneira como conhecemos hoje.

A autonomia de Santo Amaro termina em 22 de fevereiro de 1935 a partir do Decreto $n^{\circ} 6988^{2}$, outorgado por Armando de Salles Oliveira, interventor Federal no Estado de São Paulo, extinguindo o município de Santo Amaro, cujo território passa a fazer parte da cidade de São Paulo.

Com relação à herança cultural e idiossincrasias da região de Santo Amaro, as bandas constituíram-se, muitas vezes, como uma das únicas manifestações culturais de pequenas cidades interioranas, fazendo-se presentes nos momentos sociais mais importantes da cidade:

[...] No passado, as bandas foram as principais responsáveis pelas formas de lazer da comunidade, realizando retretas, desfiles, circos, festas religiosas, festas cívicas, bailes, entre outros. As retretas nos domingos reuniam na Praça os habitantes da cidade, que circulavam enquanto ouviam a música tocada no coreto. Para a autora, as bandas foram também importantes na confirmação de princípios hierárquicos. Não se concebia enterro de cidadão ilustre sem o seu acompanhamento. Elas funcionavam igualmente junto às igrejas, nas procissões dos padroeiros da cidade. Destacavam-se ainda como "orquestras de dança" responsável pelos serviços musical de festas e bailes. Animavam os "mafuás" que divertiam crianças e adultos (CRANJA, 1984, p. 82 Apud COSTA, 2011, p. 258).

De fato, conforme descrito na citação de Granja (1984), a vida social urbana de uma cidade brasileira na virada do século XIX e primeiras décadas do XX, remonta na herança cultural e no significado da sociabilidade urbana construida por essas corporações musicais.

Apesar da grandiosidade da dimensão territorial de Santo Amaro até o ano de 1877, do ponto de vista da música como um veículo de

2 Decreto n. 6.983, de 22 de fevereiro de 1935 - Acessado em 04/01/2020 https://www. al.sp.gov.br/repositorio/legislacao/decreto/1935/decreto-6983-22.02.1935.html 
transmissão, e as bandas como um das principais representações no que se refere ao coletivo como elemento de construção da identidade, é admissivel compreender que lastros culturais verificados na região central de Santo Amaro estivessem presentes nos mais longínquos bairros, justificando, em parte, a existência de bandas centenárias, atualmente em plena atividade nos municípios de Itapecerica da Serra e Embu das Artes.

No entanto, embora haja uma continuidade cultural da banda de música até os nossos dias, seja na forma ativa e orgânica, conforme os exemplos de Itapecerica da Serra e Embu das Artes (cidades da grande São Paulo que pertenciam a Santo Amaro até 1887), é preciso cautela, já que não podemos estabelecer um olhar anacrônico simplesmente transportando o sentido que elas têm hoje para as décadas próximas da virada do século XIX - XX. Não apenas pela complexidade que o espaço urbano adquiriu com o passar dos anos, mas pela forma singular que naquele momento específico se integrara aos poros da cidade.

\section{Pelas Bandas de Santo Amaro: música, pertencimento $e$ identidade}

$\bigcirc$ registro das primeiras bandas de música no Brasil remete à chegada da Corte Portuguesa em 1808. O decreto de 16 de dezembro de 1815 tanto estabeleceu a composição das bandas de música em cada regimento de infantaria e nos batalhões de Caçadores como indicou a quantidade de músicos e os instrumentos que deveriam compor essas bandas:

[...] Um mestre, um primeiro clarinete, um primeiro requinta, um segundo primeiro clarinete (suplente), um clarinete, um segundo clarinete, um músico primeiro trompa, um segundo trompa, um primeiro clarone, um baixo, um músico para o trombão ou para o serpentão, um tambor grande e uma caixa de rufo. Além disso, deveria ter quatro aprendizes entre os soldados, o que permitiria chegar ao número de 16 instrumentistas, mas não mais (SANTIACO, 1997, p. 194).

\section{1}

REV. TULHA, RIBEIRÃO PRETO, v. 6, n. I, pp. 206-237, jan.-jun. 2020 
A instrumentação das bandas se caracteriza pelo emprego de instrumentos de sopro e percussão, exceto as bandas sinfônicas que atualmente se valem da participação de instrumentos de cordas como, por exemplo, o contrabaixo acústico e violoncelo, em alguns casos. Desde que suficientemente organizadas como associações musicais, essas bandas são classificadas por múltiplas denominações: Corporação Musical, Agremiação, Grêmio Musical, Filarmônica, Clube Musical, Lira, Banda de Música, Sociedade Musical ou Banda Sinfônica, estabelecidas em corporações militares ou civis. Podem ser pequenas ou grandes, fanfarra, marcial, de coreto, banda sinfônica ou as chamadas orquestras de sopros, entre outros. "Independente da classificação, elas estão presentes nos momentos sociais mais importantes da cidade, sejam civis ou religiosos (COSTA, 2011 , p. 242)".

De acordo com Oliveira (2019, p. 65), as bandas de música estão distribuidas nas seguintes categorias:

- Fanfarra: do francês fanfare, é constituída especialmente de percussão e instrumentos de sopro lisos, como cornetas e cornetões. Apresenta ainda a característica coreográfica, como evoluções e marchas, sendo especializada em desfiles cívicos.

- Banda marcial: a banda marcial é um conjunto de executantes de instrumentos de metal e bocal, com três pistos e instrumentos de percussão, especializadas em desfiles comemorativos, artísticos, religiosos, populares e folclóricos, assim como possuem também grupos coreográficos, porta-bandeiras, balizas e dançarinos. Seu repertório principal é composto de músicas instrumentais ou populares de qualquer estilo, porém interpretadas em movimento.

- Bandas tradicionais (civis ou militares): além dos instrumentos normalmente empregados pelas bandas convencionais, as bandas tradicionais são constituídas pela diversidade de sua formação instrumental, abrangência de repertório e a utilização de instrumentos como oboé, corne-inglês, diversas espécies de clarinetes, saxofones e vasto naipe de percussão (teclados: marimba, vibrafone, xilofone, glockenspiel, tímpanos, bombos, campanas etc.) e, cordas (piano, contrabaixos e, em alguns casos, violoncelos). Essa formação pode ser alterada de acordo com a natureza das obras e, tal flexibilidade torna-a apta à execução de transcrições do repertório concebido para a orquestra sinfônica e particularmente adequada às experimentações

\section{2}

REV. TULHA, RIBEIRÃO PRETO, v. 6, n. I, pp. 206-237, jan.-jun. 2020 
da música contemporânea justificando, assim, o fato de seu já vasto repertório original ser fruto da produção artística do século XX.

- Banda sinfônica: é um termo reservado às organizações de sopros de instrumentação equilibrada, constituídas muitas vezes de 90 a 120 instrumentistas e é verdadeiramente análoga à orquestra sinfônica.

- Banda militar: as bandas militares, de formação variada, atendem às necessidades da caserna.

- Banda civil: em sua maior parte, são instituições de importância impar na vida musical, social e cultural do interior brasileiro. Em geral, elas possuem registro em cartório, sede própria, diretoria, estatutos, escolinha de instrumentistas, arquivos de grande valor musicológico, perpetuando gêneros abandonados pela música comercial.

Em relação às bandas do município de Santo Amaro, o levantamento bibliográfico inicial realizado por esta pesquisa, a partir de trabalhos acadêmicos, revistas, jornais, redes sociais e blogs, apontou para a hipótese da existência de cinco bandas de música durante o período em que Santo Amaro foi município (1833-1935): Banda Treze de Maio, Lira Euterpa, Corporação Musical Santamarense e Banda 16 de Julho, além da Banda Musical de Santo Amaro relatada no site da Prefeitura de São Paulo.

No entanto, a bibliografia, embora significativa, além de não possuir consistência suficiente sobre quantas e quais seriam de fato, as bandas de música existentes no município de Santo Amaro. Também não responde a outras questões pertinentes no que diz respeito a informações mais específicas, como por exemplo, aspectos de estratificação social em relação aos músicos que fizeram parte das referidas bandas. Em decorrência disso, algumas lacunas ainda não foram preenchidas: não nos foi possivel saber se os músicos eram moradores do bairro ou não, como eram selecionados (se por teste ou indicação), se eram contratados ou voluntários, se eram músicos profissionais ou se tinham outras carreiras, nem se eram mantidos por algum patrocínio ou pelo município. Além disso, não nos foi possivel saber o público da banda, se eram ou não cativos e nem o nível social a que pertenciam.

A revista Interlagos, em um artigo publicado no ano de 1951 e, circunstancialmente relatado pelo historiador Fatorelli (20 I 3), corrobora

\section{3}

REV. TULHA, RIBEIRÃO PRETO, v. 6, n. 1, pp. 206-237, jan.-jun. 2020 
para a estimativa da existência de pelo menos quatro bandas de música no município. Porém, a ausência de pesquisas historiográficas advindas da academia ou de órgãos oficiais e a incipiência do estado atual da pesquisa em torno deste assunto sugerem também a possibilidade desse número ser menor ou até mesmo maior. Vale ressaltar que nomes como "Lira", "Euterpe" e "Furiosa" até hoje são utilizados como referência a esse modelo de agrupamento musical e, por isso, não podemos descartar a hipótese de que a mesma banda seja retratada com nomes distintos nas diferentes fontes consultadas como, por exemplo, Banda Musical de Santo Amaro e Corporação Musical Santamarense podem ser a mesma banda.

Posto isso, embora a pesquisa ainda não reúna elementos suficientes que comprovem a existência de todas essas bandas e nem a não existência de parte delas, trataremos, portanto, neste estudo, como instituições independentes e autônomas as bandas: Treze de Maio, Lira Euterpa, Corporação Musical Santamarense, Banda Musical de Santo Amaro e Banda 16 de Julho.

Em relação às corporações musicais Treze de Maio, Lira Euterpa e Banda Musical de Santo Amaro, esta pesquisa reuniu poucas informações. Entretanto, sobre a Corporação Musical Santamarense destacam-se alguns dados importantes e, dentre eles, o do registro iconográfico por ocasião da comemoração dos 56 anos da corporação disponibilizada no blog de Fatorelli (2013) em um recorte do jornal A TRIBUNA, de 1972 (Figura 2).

\section{4}

REV. TULHA, RIBEIRÃO PRETO, v. 6, n. I, pp. 206-237, jan.jun. 2020 


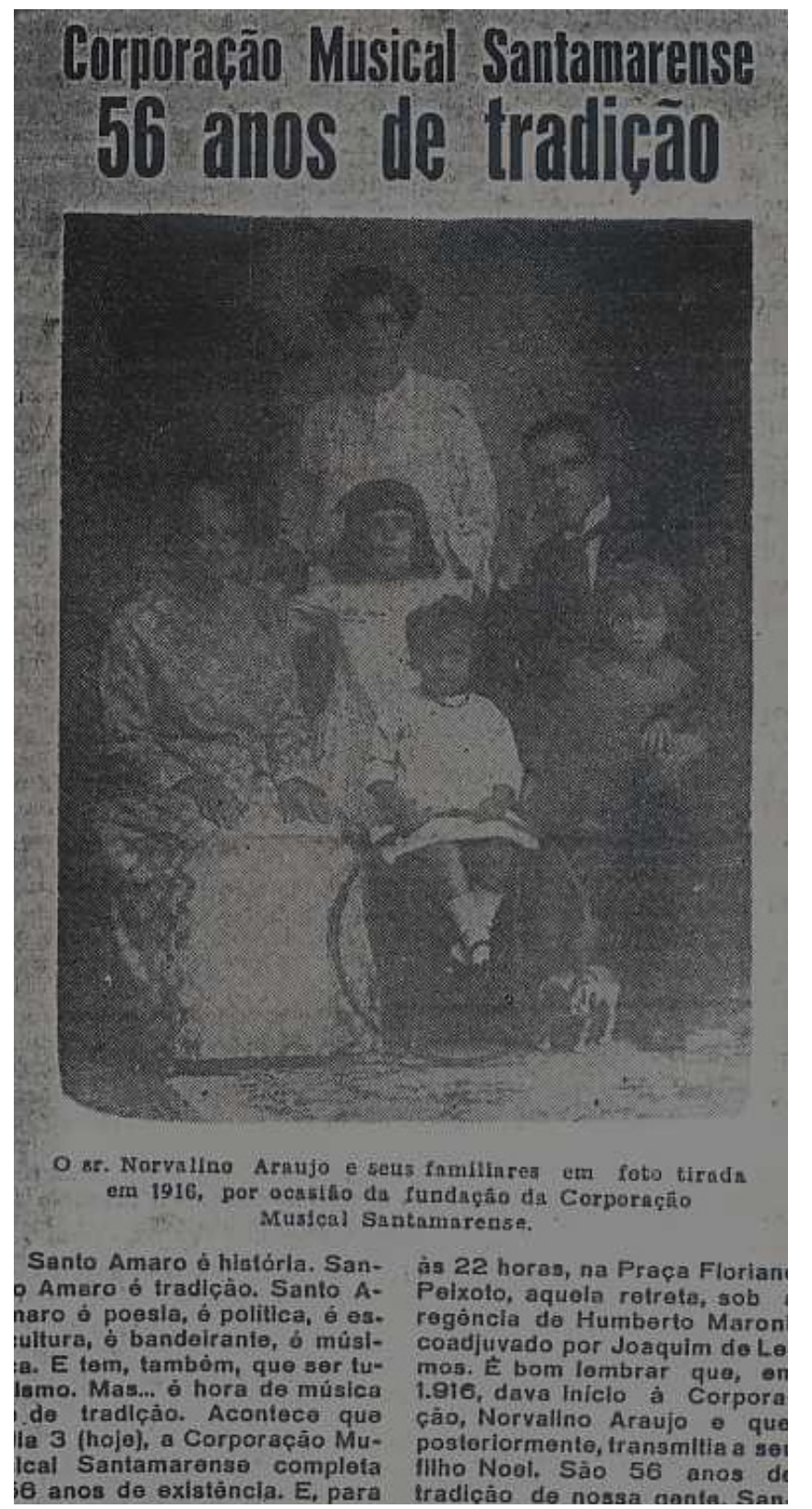

Figura 2. Comemorações dos 56 anos da Corporação Musical Santamarense. Fonte: Jornal A TRIBUNA, 1972. Acervo pessoal de Cláudia Simone Pereira, neta do Sr. Luiz Chile.

\section{5}

REV. TULHA, RIBEIRÃO PRETO, v. 6, n. 1, pp. 206-237, jan.-jun. 2020 
Outro registro importante no que se refere à representação e à memória da Corporação Musical Santamarense se dá em uma matéria de 30 de julho de 1988, no jornal Gazeta de Santo Amaro. A matéria apresenta uma espécie de passeio da memória através de relatos do músico Luiz Chile, na ocasião com 72 anos, um dos mais antigos moradores da região na década de 80 (Figura 3).

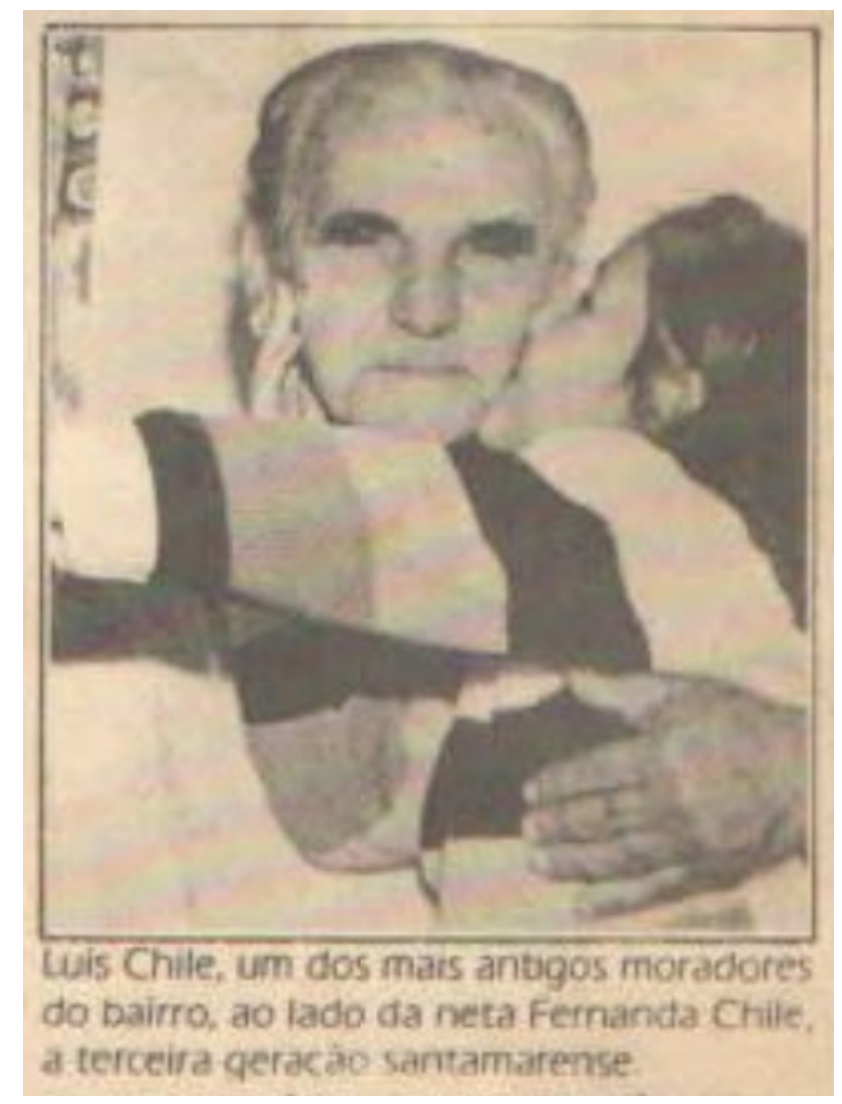

Figura 3. Luiz Chile - músico da Corporação Musical Santamarense. Jornal GAZETA de SANTO AMARO, 30 jutho de 1988. Acervo pessoal de Carlos Fatorelli.

Sobre a atuação de Luiz Chile, o músico relata que ingressou na Corporação Musical Santamarense em 1931, aos 15 anos como aprendiz, recebendo as primeiras lições de música de Norvalino Branco

\section{6}


de Araújo (fundador da referida banda - Figura 2), iniciando como músico na banda apenas aos 18 anos, tocando trombone e, mais tarde, saxhorn.

Segundo Chile (1988), a atuação da Corporação Musical Santamarense não se limitava apenas ao coreto. A banda tocava em festas, congadas, procissões e romarias, além das retretas na Praça Floriano Peixoto, o que nos faz imaginar a amplitude e a ecleticidade do seu repertório. Os ensaios aconteciam em sua sede, situada na Rua Isabel Schmidt 221 . Em relação à quantidade de músicos, a Corporação Musical Santamarense dispunha do efetivo de 30 músicos até a década de 1980, quando, provavelmente por falta de recursos, encerrou suas atividades. Seu último regente foi Amaro Alves Alvim que, além da função de mestre de banda, trabalhava como funcionário dos Correios Paulista (FATORELLI, 2013).

Em relação à formação de bandas civis no Brasil, segundo Hardman (2002), predominantemente na cidade de São Paulo e, sobretudo de origem amadora e operária, foi instituída a partir dos processos de industrialização e urbanização do espaço público. "Tais elementos contribuíram substancialmente para a organização social e cultural operária, incluindo aí, suas formas de sociabilidade. Portanto, a música foi um elemento característico desta fase histórica da formação de classes em São Paulo (SILVA, 2018, p. 18)".

No que se refere aos aspectos sociais, as bandas, em sua maioria, desempenham um papel muito significativo em relação à coletividade, pertencimento e construção da identidade do povo de um lugar. Sobre a atuação da banda em cerimônias cívicas, seja em eventos privados ou em locais públicos como repartições e praças, sua participação se dá, muitas vezes, como música ambiente desde os momentos que antecedem o pronunciamento de autoridades presentes à execução do Hino Nacional e outros hinos cívicos (conforme a ocasião) até o pós-cerimonial, despedindo os presentes ao som de dobrados ou temas do imaginário popular. "Com elas, os eventos públicos ganham um novo e poderoso ingrediente, sendo este capaz de mobilizar uma parcela significativa da população, despertando sentimentos coletivos, pois as bandas estão presentes nos momentos mais importantes da sociedade (COSTA, 2011, p. 259)". 
Justamente em uma dessas ocasiões, Chile (1988) relembra com tristeza um fato que marcou sua permanência na Corporação Musical Santamerense, a "Cerimônia do Adeus" - evento que contou com a presença de muitos moradores de Santo Amaro e de autoridades como o prefeito de São Paulo, Faria Lima, e o governador Abreu Sodré em 27 de março de 1969, no Largo 13 de Maio:

Na administração Faria Lima, foi desativada a última linha de bonde que ligava Santo Amaro à Praça João Mendes. Houve grande solenidade com a presença dos moradores e de importantes autoridades. Na despedida do bonde, tocamos o tempo inteiro, emocionados com a partida da condução que tantos anos serviu a população (CHILE, 1988 Apud GAZETA DE SANTO AMARO, 30 de julho de 1988).

No que diz respeito as questões que se relacionam entre música, coletividade e pertencimento, ligadas diretamente à memória e à identidade cultural santo-amarense, a maestrina Mônica Giardini', que cresceu no Brooklin (bairro que pertenceu ao município de Santo Amaro), além de ter participado em forma de passeio com sua mãe da última viagem do bonde que ligava Santo Amaro à Praça João Mendes, comenta sobre a representatividade e a importância que as bandas de música tinham na região, ao relembrar do passeio no bonde e de quando ia com seus pais aos finais de semana assistir a banda no coreto da Praça Floriano Peixoto (Praça central de Santo Amaro), em meados dos anos 1960:

[...] Eu morava no centro de São Paulo e mudamos aqui para o Brooklin, que agora é chamado Vila Cordeiro, eu tinha entre quatro a seis anos. Era uma tradição nossa, naquela época, passear de carro era tudo de bom (minha mãe que dirigia), íamos para Santo Amaro ouvir a banda de Santo Amaro. Nasci em 1962, então, isso foi

3 Mônica Giardini é regente titular da Banda Sinfônica Jovem do Estado de São Paulo desde sua estreia em 1993, regente e diretora musical da Banda Sinfônica Paulista, atua como clinician do Projeto Sopro Novo Bandas da Yamaha do Brasil, em diversas cidades do país, tendo escrito e publicado o Caderno de Regência da coleção deste Projeto e é professora de regência na Faculdade FACEC -ES desde 2016. Fonte: Currículo Lattes http://lattes.cnpa.br/644589/840556571 - Acessado em 30/06/2020

\section{8}

REV. TULHA, RIBEIRÃO PRETO, v. 6, n. I, pp. 206-237, jan.-jun. 2020 
provavelmente entre 66/67. Me lembro que em todos esses anos, nós íamos aos domingos passear em Santo Amaro. Tenho muito carinho pela banda, como toda criança, meus pais ficavam sentados no banco da Praça e eu regendo a banda assim como toda criança adora fazer, correndo em volta do coreto e regendo a banda, marchando, brincando (risos), em volta do coreto havia bêbado dançando e tudo que tinha direito. Uma coisa que acho interessante e gostaria de destacar, diz respeito ao público que assistia essas bandas. Por exemplo, meu pai pertencia a uma classe média que estava emergindo, uma família nova e aquilo para nós era um passeio, assistir a banda era um programa de domingo. Minha mãe me vestia de vestidinho e dizia: "Vamos passear de carro, vamos lá ver a banda". Era muito bom, não sei porquê isso não se manteve. [...] (sobre a última viagem do bonde de Santo Amaro), isso foi quando eu era pequena, minha mãe nos levou para fazer a última viagem no bonde. Não pegamos em Santo Amaro, pegamos na Joaquim Nabuco, onde eu morava com meus pais, fomos até a praça João Mendes e depois pegamos de volta e descemos na Joaquim Nabuco, por isso não tive a oportunidade de ouvir as bandas que estavam tocando naquele dia, mas, fiquei muito feliz de ter participado dessa última viagem (CIARDINI, 2020).

Ainda sobre identidade e pertencimento, Chile (1988) destaca - concurso de bandas realizado em 1978 em Diadema/SP, em que, dentre inúmeras bandas de várias regiões, Santo Amaro obteve $03^{10}$ lugar. Destacam-se também outros registros sobre a participação da Corporação Musical Santamarense em outros concursos como uma nota no jornal A TRIBUNA de 26 de janeiro de 1979 (Figura 4). 


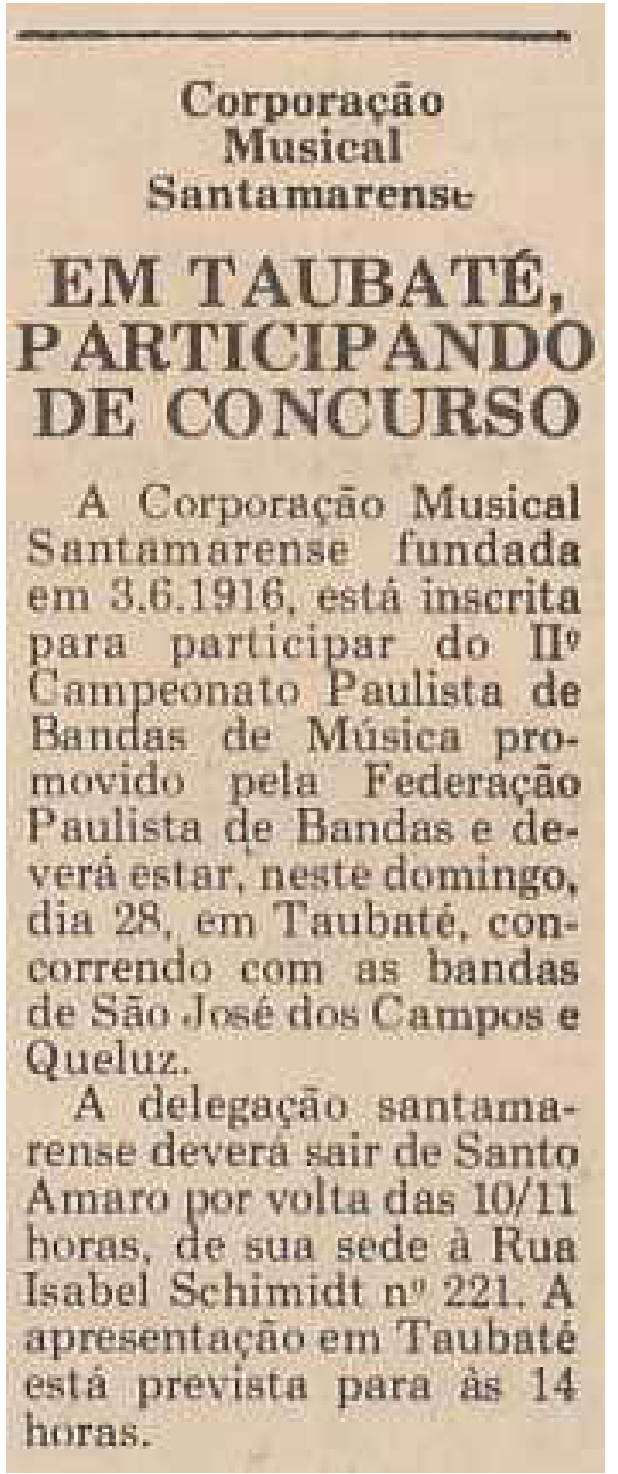

Figura 4. Anúncio da participação da Corporação Musical Santamarense no $\|^{\circ}$ Campeonato de Bandas de Música em Taubaté - SP.

Fonte: Jornal A TRIBUNA, 26 janeiro de 1979. Acervo pessoal de Carlos Fatorelli. 
Sobre qual teria sido a primeira banda do município de Santo Amaro, segundo Fatorelli (20 I 3), a "Lira Euterpa foi a primeira corporação musical do município de Santo Amaro, fundada em 1865 [...] e, possuía como mestre o maestro Miguel Arcanjo (FATORELLI, 20 I3)".

No tocante à Banda 16 de Julho (Figuras 5-6), em uma publicação de março de 1951, na Revista Interlagos, em um texto que aborda as tradições e herança cultural do antigo município, evidenciam-se o saudosismo e o entusiasmo, mencionando a banda como um dos símbolos da cultura santo-amarense:

Santo Amaro antigo tem tradições magníficas que trazem até a cidade atual, estuante de seiva, a singeleza e simplicidade dos costumes dos nossos saudosos antepassados. Ainda há os que se recordam de tudo - que ficou pelo século passado como, por exemplo, o gosto musical da população que ficava horas e horas, embevecidas, ouvindo os dobrados e, marchas executadas pelas corporações musicais uniformizadas tão ao sabor da época. $\bigcirc$ clichê apresenta à famosa "Banda 16 de Julho", em uma de suas domingueiras passeatas, no ano de 1895, vendo-se como num painel de fundo (Figura 5), sobressair-se os vagões do famoso "trenzinho" que ligava Santo Amaro à Capital em 2 horas de viagem (REVISTA INTERLACOS, 1951, p. 32). 


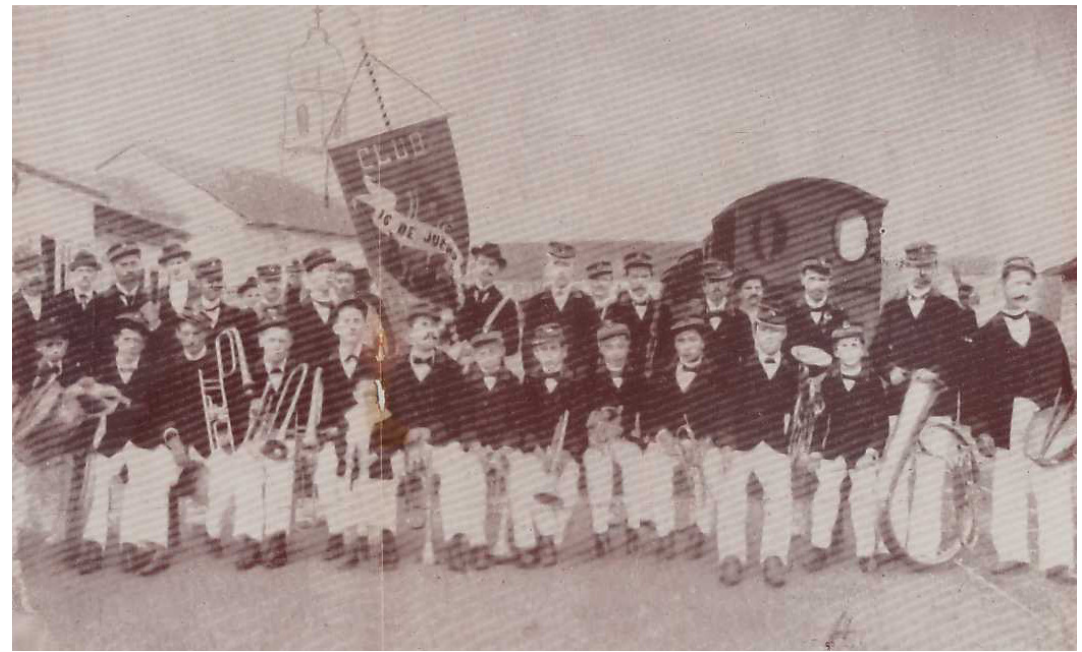

Figura 5. Banda 16 de Julho. Local: Largo Treze de maio, 1895. Fonte: Revista Interlagos, 1951, p. 31 . Acervo pessoal de Carlos Fatorelli.

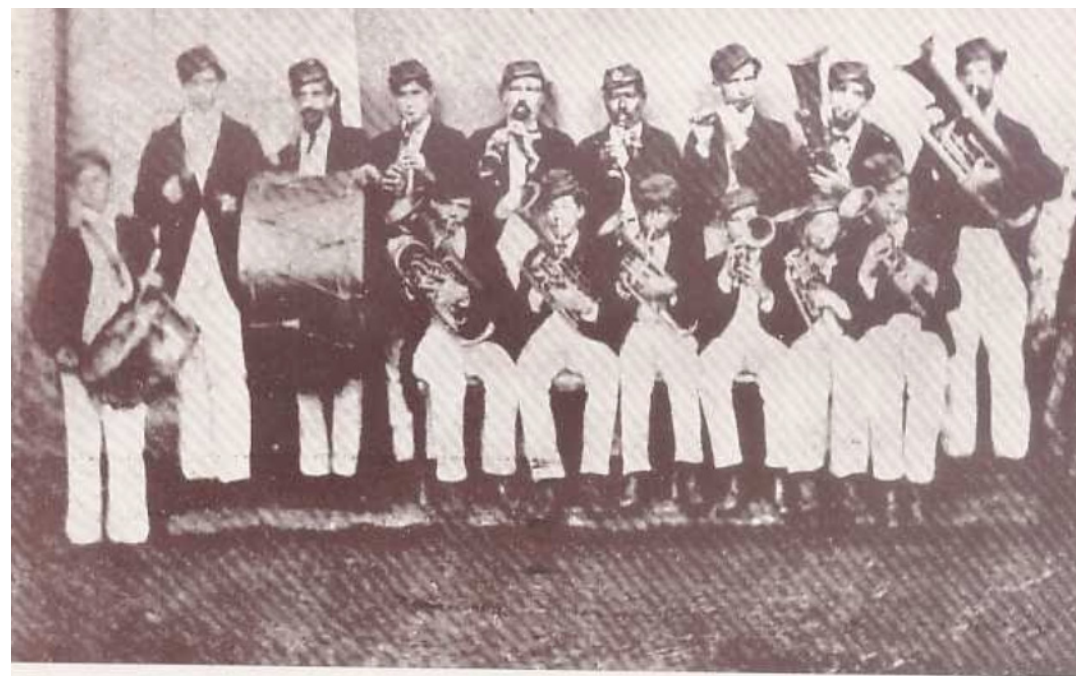

Eanto Amaro antigos, a nossa pagina que recorda tradiçôes da cidade de Paulo Eirỏ, tem causado a melhor das impressóes $\mathrm{em}$ todos os nossos leitores que, tam. béa, nos têm trazido a sua colaboraçio na forma de fornecimento de fotografia interessantes, como por exemplo a que ilustra estas linhas e que fixa uma corpo. raçào musical que andou alegrando os ares santamarenses lá pelo longinguo ano de 1 k70: Por mais que nos esforcassemos, santamarenses lá pelo longinguo ano setts componentes, mas aqui ficam êles retratados como uma homenagem muito sincera de Interlagos a revista que surgiu para cultuar as tradiçóes históricas de nossa centenária rindoto

Figura 6. Banda 16 de Julho: Excerto de matéria publicada na Revista Interlagos no ano de 1951.

Fonte: Revista Interlagos, 1951, p. 32. Acervo pessoal de Carlos Fatorelli.

\section{2}




\section{Pra ver a banda passar: herança cultural de Santo Amaro}

\section{Maestro Elias Evangelista da Silva Filho}

Concernente à herança cultural de Santo Amaro e relacionado às práticas coletivas, ressaltam-se as manifestações culturais por intermédio de bandas como a Corporação Musical Bertinho Mandú da cidade de Embu-Guaçu (antiga Banda de Embu-Guaçu), e, também, das centenárias, Corporação Musical Imaculada Conceição de Itapecerica da Serra e Banda Municipal de Embu das Artes.

Ressalta-se a ocorrência de interfaces relacionada às bandas Corporação Musical Imaculada Conceição de Itapecerica da Serra e Banda Municipal de Embu das Artes, como por exemplo, o fato de que ambas as bandas, no período estabelecido entre os anos de 1993 a 2017, estiveram sob a batuta do mesmo regente, o maestro Elias Evangelista da Silva Filho (1948), estabelecendo, portanto, uma interrelação entre elas. Essa correspondência proporcionou a comunhão de repertório, como também um processo migratório de músicos entre as duas bandas.

Entre outras peculiaridades geradas a partir dessa simultaneidade, está a participação e algumas conquistas de campeonatos estaduais de bandas e fanfarras do Estado de São Paulo, visto que nesses campeonatos, no sentido de se fortalecerem, apesar de nessas ocasiões serem concorrentes, fora do palco, uniam-se na torcida de uma pela outra.

Concomitantemente aos trabalhos frente às bandas de ltapecerica da Serra e Embu das Artes, Elias Evangelista da Silva Filho integrou, como clarinetista, a Orquestra Sinfônica do Estado de São Paulo (OSESP), até 1996, período em que a orquestra esteve sob a regência do maestro Eleazar de Carvalho. Além de sua expressividade enquanto músico e arranjador, Elias Evangelista, talvez, seja um dos poucos representantes da figura chamada de "mestre de banda", função que em sua essência é tipificada pelo acúmulo das funções de regência, preparação de repertório e do exercício da atividade no ensino técnico de todos os instrumentos que compõem uma banda de música por intermédio da escolinha de instrumentistas. 


\section{Corporação Musical Imaculada Conceição de Itapecerica da Serra - SP}

Segundo informações na página oficial do Centro Musical Imaculada Conceição4, a Corporação Musical Imaculada Conceição de Itapecerica da Serra, ou "CMIC", como também é chamada carinhosamente pelos seus componentes, é uma entidade beneficente sem fins lucrativos fundada no ano de 1893, uma das bandas mais antigas no Brasil em funcionamento.

Atualmente, a banda é formada por músicos amadores com idade entre 10 e 75 anos. Assim como as demais bandas desse segmento, além do prazer de tocar, seus componentes cultivam um ambiente agradável em uma espécie de segunda família, unida pela amizade e amor à música.

Quanto à instrumentação da Corporação Musical Imaculada Conceição, em geral conta com instrumentos normalmente empregados pelas bandas tradicionais, dividindo-se nos naipes de madeiras - flautas, clarinetes e família de saxofones; metais - trompetes, trombones, eufônios e tubas; percussão - glockenspiel, tom-tons, bateria, bombos, campanas, pratos etc.

A banda possui registro em cartório, sede própria, diretoria, estatuto e escolinha de instrumentistas. Sua sede está situada na rua Dr. Augusto de Queiróz, 77 - Centro de Itapecerica da Serra - SP, local onde se realizam os ensaios $e$ as aulas de instrumento (Figura 6).

4 https://www.facebook.com/cmic 1983/ - Acesso em 30 de abril de 2020.

\section{4}

REV. TULHA, RIBEIRÃO PRETO, v. 6, n. I, pp. 206-237, jan.-jun. 2020 

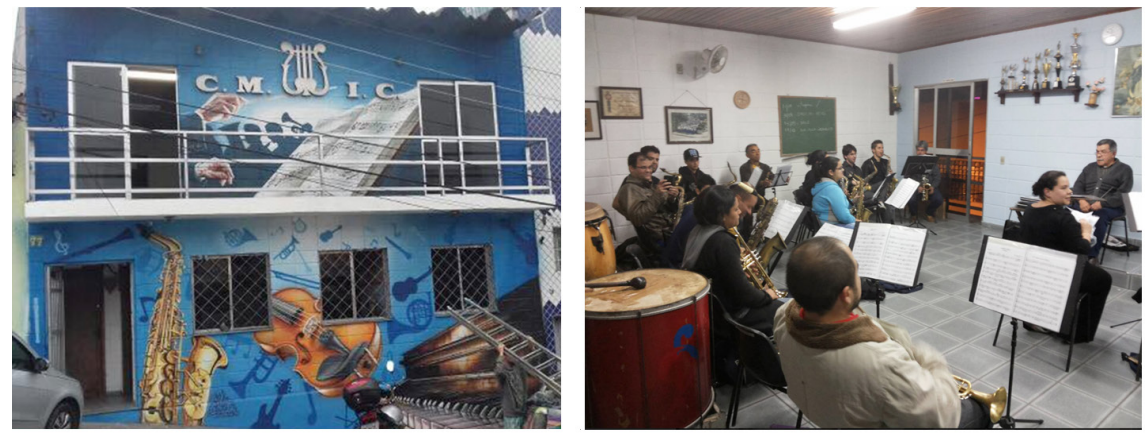

Figura 6. Sede da Corporação Musical Imaculada Conceição de Itapecerica da Serra - SP. Fachada externa e pavimento interno superior, local onde são realizados os ensaios da banda.

Fonte: Página oficial da $\mathrm{CMIC}^{5}$ - Corporação Musical Imaculada Conceição. Acessado em 01/05/2020.

\section{Banda Municipal de Embu das Artes - SP}

A Banda Municipal de Embu das Artes é uma entidade civil, não partidária, sem fins lucrativos e de tradição secular. Ela é gerida e mantida pela Prefeitura de Embu das Artes, estando diretamente subordinada à Secretaria de Cultura.

Ao longo dos anos, o efetivo da banda tem variado entre 30 e 50 integrantes, contando com um inspetor, um agente de apoio, que auxilia a banda na logística quanto à montagem, desmontagem e transporte dos instrumentos para apresentações e ensaios. Quanto ao arquivo musical, organização e armazenamento das partituras e pastas, a banda conta com a colaboração de um dos seus músicos, a clarinetista Débora Simões, musicista da banda desde 1993, que, de forma voluntária, desenvolve essa função.

No presente, a banda conta com cerca de 35 músicos divididos entre os naipes de madeiras - flautas, clarinetes, familia de saxofones e fagote; metais - trompetes, trombones, eufônios e tubas; percussão

5 https://www.facebook.com/cmic 1983/photos/a.221217777994618/617044191745306 l?type $=3$ Etheater - Acessado em 0 1/05/2020 
- bateria, bumbo sinfônico, tímpanos, glockenspiel, bombos, campanas, pratos etc.

Com relação à estrutura artística hierárquica, a Banda Municipal de Embu das Artes estrutura-se da seguinte forma: Maestro (mestre de banda), Maestro assistente (contramestre), Spalla e Chefes de naipe, distribuidos segundo os instrumentos de cada categoria, ou seja, cada família de instrumentos possui um líder - responsável pelo equilíbrio sonoro do naipe, afinação, execução de solos e distribuição das vozes entre outras peculiaridades.

Atualmente, a Banda Municipal de Embu das Artes (Figura 7) está sob a regência de Hamilton Oliveira, que assumiu a condução dos trabalhos em 2017, após a aposentadoria do maestro Elias Evangelista da Silva Filho.

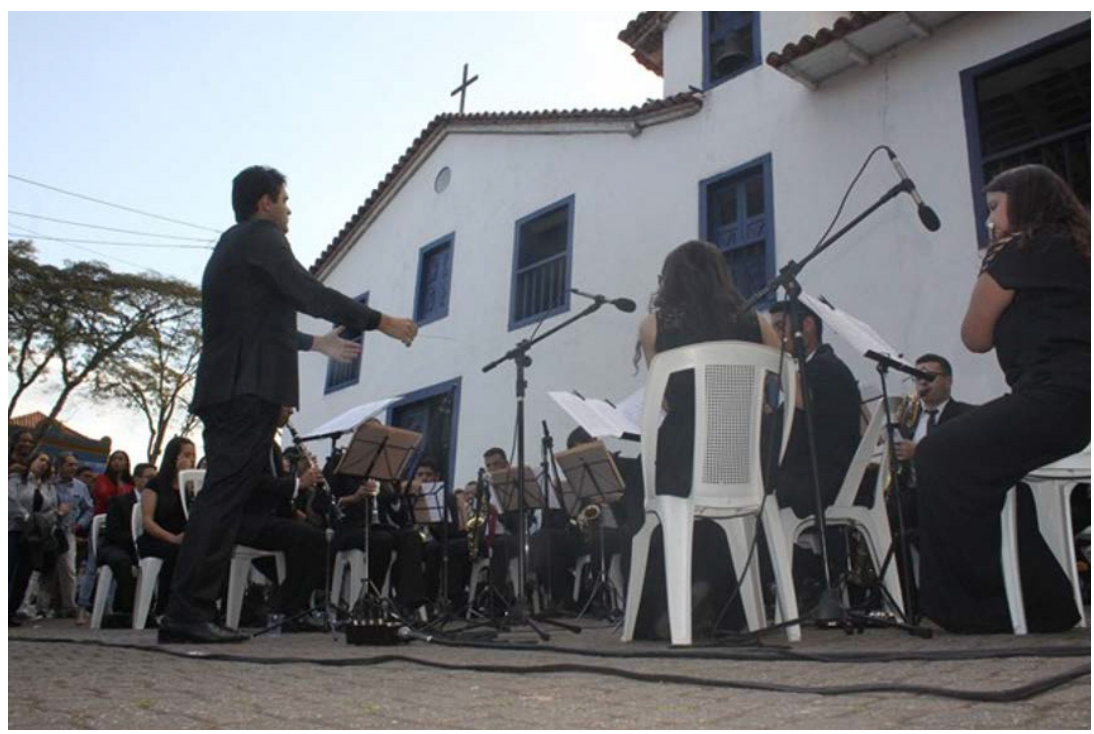

Figura 7. Concerto da Banda Municipal de Embu das Artes sob a regência do maestro Hamilton Oliveira. Centro histórico - Museu de Arte Sacra de Embu das Artes, 2018.

Fonte: http://cidadeembudasartes.sp.gov.br/embu/portal/noticia/ver/1 1260 - Acessado em 30/01/2020 
Sobre a composição social do efetivo da Banda Municipal de Embu das Artes, constata-se que, a maioria dos componentes reside na cidade de Embu das Artes e compõe a faixa etária de 15 a 60 anos, porém, com predomínio das idades entre 18 e 28 anos.

A forma de ingresso na banda acontece por intermédio de processo seletivo, convite elou também de forma voluntária, variando de acordo a necessidade do momento. No entanto, 30\% do efetivo atual ingressaram como estagiários, oriundos da antiga escolinha de instrumentistas da banda (até 2001), projeto PIM (2001-20/4) e da Escola Municipal de Música de Embu das Artes, instituição criada em 2014 , que tem como finalidade manter um centro de formação musical que, entre as principais funções, está o objetivo de alimentar a Banda Municipal com novos músicos. Sobre a remuneração dos integrantes da banda, essa acontece por intermédio de uma ajuda de custo a partir de uma bolsa mensal no valor de 350 reais, acrescido do auxílio de uma cesta básica.

Entre os acontecimentos que marcam a trajetória da banda, destaca-se a conquista do bicampeonato estadual de Bandas, ocorrido na cidade de Itapira - SP, no ano de 1996.

Para efeito comparativo, a partir de registros iconográficos, uma das principais fontes para esta pesquisa, foi-nos possivel observar a Banda Municipal de Embu das Artes, ao longo dos últimos 90 anos em dois momentos distintos: o primeiro - registro de 1930 (Figura 8) e, num segundo momento, um registro de 1968, conforme se observa na figura 9. A imagem de 1968 retrata a participação da banda tocando ao vivo no filme "Embu", de Roberto Santos. Vale ressaltar que parte da produção da trilha do filme é da Banda Municipal de Embu das Artes. 


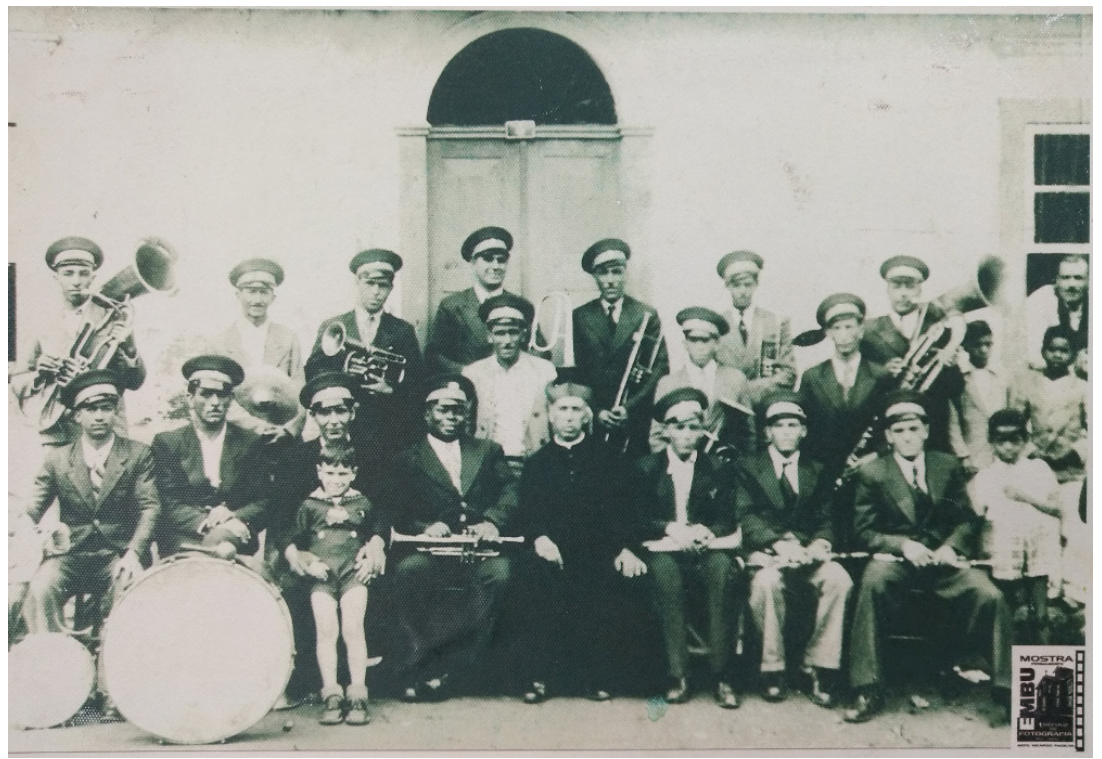

Figura 8. Banda Municipal de Embu - anos 30. Coleção de Pedro Saturnino da Silva. Fonte: Acervo da Prefeitura da Estancia Turística de Embu das Artes.

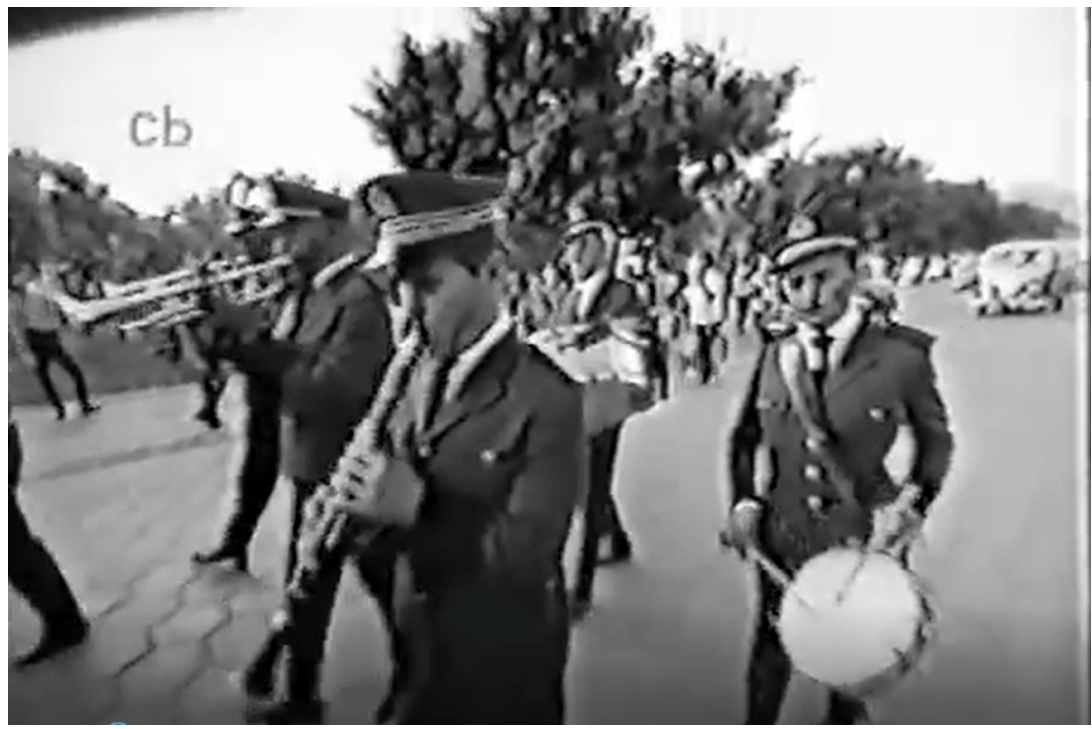

Figura 9. Participação da Banda Municipal de Embu das Artes no filme "Embu" (1968), de Roberto Santos (Início do período considerado "Cinema Novo"). ECA / USP, 1968. Fonte: https://www.youtube.com/watch?v=RrpUvu04yio - Acessado em 06/02/2020 
Levando em consideração a continuidade do legado centenário da Banda Municipal de Embu das Artes, é importante destacar que alguns fatores corroboraram para que o trabalho e o foco principal da banda não se perdesse em meio à onda migratória, que levou muitas bandas a abandonarem o coreto, buscando um status mais elitizado, optando por um público mais seleto, fato que, na maioria das vezes, está essencialmente ligado à gestão artística do maestro.

Partindo desse ponto de vista, no que se refere à escolha do atual maestro da Banda Municipal de Embu das Artes, assim como acontece em outras bandas desse segmento, para continuidade do legado, a escolha do maestro se dá por diversas maneiras. Entre as principais questões levadas em consideração é que a indicação parta da própria banda, representada na figura de seus integrantes, atrelada ao fato de que esse regente possua relações intrínsecas com a banda, como no caso do atual maestro Hamilton Oliveira.

Hamilton Oliveira é natural de Embu das Artes (39 anos), seus primeiros contatos com a Banda Municipal acontece aos 13 anos de idade, quando iniciou seus estudos de clarinete na antiga escolinha de instrumentistas, com o então mestre de banda e clarinetista Elias Evangelista da Silva Filho, no mesmo ano, Hamilton ingressa na banda na função de terceiro clarinete.

Como discípulo do maestro Elias, em 201 1, Hamilton Oliveira assume a função de maestro assistente (contramestre) da banda e, em 2013, a convite da Secretaria de Cultura, assume também a coordenação geral de uma frente de trabalho para criação e implantação da Escola Municipal de Música de Embu das Artes.

Quanto a sua formação, Hamilton Oliveira é bacharel em clarinete pela UNESP (2006) recebendo orientação de Sérgio Burgani e Luis Afonso Montanha. Também foi aluno da Escola Municipal de Música de São Paulo tendo como professor os clarinetistas Edmilson Nery e João Francisco Correa. Estudou regência com os maestros Vitor Gabriel, Samuel Kerr, Mônica Giardini e Carlos Moreno. 


\section{Leis municipais que orientam a Banda Municipal de Embu das Artes}

Os primeiros levantamentos efetuados por esta pesquisa apontam as origens da Banda Municipal de Embu das Artes para meados do século XVIII, período do Brasil colônia na aldeia M'Boy (hoje Embu das Artes); no entanto, essa pesquisa não teve acesso a fontes primárias. Todas as informações no que diz respeito às origens da banda de Embu até a primeira lei de 1963, que transforma a Sociedade Musical Nossa Senhora do Rosário na Banda de Música Municipal de Embu, refere-se a dados consultados em fontes secundárias como, por exemplo, o site da Prefeitura de Embu das Artes e o jornal Correio Embuense na edição de dezembro de 2014.

Contudo, embora a consulta não tenha se dado em fontes primárias, há uma corroboração entre as informações apresentadas no Correio Embuense (2014) e no site da Prefeitura de Embu das Artes. $O$ Correio Embuense cita que a primeira formação da banda de Embu se deu a partir de um grupo de índios e negros orientados por padres jesuítas com a finalidade de acompanhar procissões e festividades folclóricas entre outras atividades religiosas (CORREIO EMBUENSE, dezembro de 2014 , p. 5). Em convalidação às informações expostas pelo jornal, os dados disponíveis no site da Prefeitura de Embu das Artes indicam o ano de 1910 como o período aproximado de quando a Sociedade Harmônica M'boyense sucedeu a banda de música da aldeia M'Boy composta por índios guaranis ${ }^{6}$ ou seja, confirma a existência de uma banda de música proveniente da aldeia M'Boy composta por índios, deixando apenas de mencionar os negros, conforme descrito pelo jornal Correio Embuense.

No site da Prefeitura também consta o nome de maestros que fizeram parte da construção histórica da banda. Entre eles estão Saturnino Canudo, Rossini, Antenor Carlos Vaz, Luiz Abdo e Elias Evangelista da Silva Filho.

Com relação à atuação, com mais de um século de existência, além dos registros iconográficos, essa pesquisa destaca algumas leis que orientam a criação da banda como também norteiam sua finalidade

6 http://cidadeembudasartes.sp.gov.br/embu/portal/noticia/ver/526 - Acessado em $01 / \overline{05 / 2020}$ 
e diretrizes orçamentárias, como, por exemplo, o Plano Municipal de Cultura de 2012.

A lei ${ }^{7}, n^{\circ}$ 175, de 28/11/1963 - a primeira encontrada por esta pesquisa -, em seu artigo $1^{\circ}$, transforma a Sociedade Musical Nossa Senhora do Rosário na Banda de Música Municipal de Embu:

Annis Neme Bassith, Prefeito Municipal de Embu, faço saber que a Camara Municipal decretou e eu promulgo a seguinte lei:

Art. $1^{\circ}$ - Fica transformada em "BANDA DE MÚSICA MUNICIPAL DO EMBU", a Sociedade Musical Nossa Senhora do Rosário, sob a regência do Maestro Antenor Carlos Vaz (LEl № 175, DE 28/11/1963).

Outra lei importante no que diz respeito à música na cidade de Embu das Artes é a lei nº 752, de 17/04/1979, que cria a "Banda Musical" da Guarda Mirim Municipal de Embu e dá providências correlatas?:

Joaquim Mathias de Moraes, Prefeito Municipal de Embu, faço saber que a Câmara Municipal decretou e eu promulgo a seguinte lei:

Art. $1^{10}$ - Fica criada na estrutura da CUARDA MIRIM MUNICIPAL DE EMBU, diretamente subordinada ao Senhor Presidente, a "BANDA MUSICAL" da GUARDA MIRIM MUNICIPAL DE EMBU

Parágrafo Único - A Banda será dirigida por maestro indicado pelo Presidente às expensas da Guarda Mirim Municipal de Embu (LEl № 752, DE 17/04/1979)

Quanto à reestruturação da banda, há a lei $\mathrm{i}^{10} 2769$, de 17 de setembro de 2014 que "dispõe sobre à restruturação e o funcionamento da Banda Municipal de Embu das Artes, e dá outras providências" como a criação da Escola Municipal de Música:

7 https://eismunicipais.com.br/a/sp/e/embu-das-artes/lei-ordinaria/1963/17/175/ lei-ordinaria-n-175-1963-transforma-em-banda-de-musica-municipal-do-embua-sociedade-musical-nossa-senhora-do-rosario-e-da-outras-providencias-196311-28 - Acessado em 02/05/2020

8 https://leismunicipais.com.br/a/sp/e/embu-das-artes/lei-ordinaria/1979/75/752/ lei-ordinaria-n-752-1979-cria-a-banda-musical-da-guarda-mirim-municipal-deembu-e-da-providencias-correlatas-1979-04-17 - Acessado em 02/05/2020

9 https:/leismunicipais.com.br/a/sp/e/embu-das-artes/lei-ordinaria/201 4/277/2769/leiorganica-embu-das-artes-sp - Acessado em 02/05/2020 
Francisco Nascimento de Brito, Prefeito, no uso de suas atribuições legais: Faço saber que a Câmara Municipal, aprovou e eu promulgo a seguinte lei:

Art. $1^{\circ}$ Reestrutura a Banda Musical Municipal de Embu denominada "Banda Municipal de Embu das Artes".

Art. $2^{\circ}$ São objetivos e diretrizes da Banda Municipal de Embu das Artes:

I - realizar concertos no Município, prioritariamente, nos bairros, centros culturais, praças e feiras e fora dele, difundindo a música erudita, folclórica e popular;

II - manter intercâmbio com entidades musicais dos demais Municípios, Estados e Países;

III - prestar assistência à Escola Municipal de Música;

IV - auxiliar no desenvolvimento da Escola Municipal de Música;

V - divulgar a música erudita, para elevação cultural da população;

VI - participar ativamente dos objetivos culturais das demais Secretarias

(LEI № 2769 DE 17 DE SETEMBRO DE 2014).

\section{Do coreto à sala de espetáculo: a proeminência das bandas no ambiente da música de concerto}

Como símbolo de progresso, algumas bandas de projeção nacional já nasceram configuradas para apresentações em salas de concerto como, por exemplo, a Banda Sinfônica do Estado de São Paulo (1989), Banda Sinfônica do Conservatório de Tatuí (1992), Banda Sinfônica Jovem do Estado de São Paulo (1993) e a Banda Sinfônica do Exército Brasileiro (2002) entre outras.

Há também bandas que trocaram as praças e o coreto pelas salas de concerto. De alguma forma, abandonando uma de suas principais funções, ou seja, proporcionar o acesso desse tipo de música a uma parte da população que, por uma série de fatores, socioculturais ou financeiros, não teriam acesso a esse tipo de conteúdo musical se não fosse pela atuação das bandas em ambientes como praças e coretos.

O objetivo deste estudo, entretanto, não busca fazer uma defesa ao "não progresso" das bandas, pelo contrário, para sobrevivência, é importante que essas bandas cresçam, abranjam outros espaços e 
frequentem também as salas de concerto, porém, que não venham por causa disso, abandonar sua principal vocação.

A partir disso, a reflexão que nos toca, diz respeito à urgência pela preservação dessas tradições, trazendo em memória um período não muito distante, onde notabilizou-se uma parte da sociedade que assistiu, de braços cruzados (sobretudo gestores da máquina pública), à extinção de bandas como as de Santo Amaro, assim como outras importantes instituições que compõem o eixo Conisud'o (região que até 1877 pertencia a Santo Amaro), como, por exemplo, o fim da Banda de Música Municipal de Taboão da Serra - SP, criada pela lei complementar' " no 10, de 09/06/1992, banda cuja as origens remontam a década de 1960'2.

$\mathrm{Na}$ esteira desses acontecimentos, recentemente, mais especificamente no ano de 2017, a classe artística e parte da população acompanharam perplexos os desdobramentos que culminaram, no trágico apagar das luzes da Banda Sinfônica do Estado de São Paulo, principal representação do segmento no Brasil e na América Latina.

De certa maneira, as deflagrações mencionadas acima emitem um alerta no que se refere à necessidade de suporte por parte do poder público para preservação e continuidade do trabalho das bandas, principalmente, de instituições centenárias como as de Itapecerica da Serra e Embu das Artes, como também, apoio a outras instituições do Conisud, como a Corporação Musical Bertinho Mandu da cidade de Embu-Guaçu - SP, e o retorno da Banda de Música Municipal de Taboão da Serra - SP.

10 CONISUD é um Consórcio Intermunicipal da Região Sudoeste da Grande São Paulo, constituído aos 21 de maio de 2001 por Municípios da Região Sudoeste a saber: Embu das Artes, Embu-Guaçu, Itapecerica da Serra, Juquitiba, São Lourenço da Serra e Taboão da Serra.

Il https://leismunicipais.com.br/a/sp/t/taboao-da-serra/lei-complementar/1992/1/10/leicomplementar-n-10-1992-criacao-da-banda-de-musica-municipal-de-taboao-da-serra - Acessado em 03/05/2020

12 Jornal $\bigcirc$ Taboanense, $\mathrm{Ol}$ de julho de 2015. https://www.otaboanense.com.br/musicosdo-futuro-homenageiam-pioneiro-das-bandas-de-taboao/ - Acesso 03/05/2020

\section{3}

REV. TULHA, RIBEIRÃO PRETO, v. 6, n. I, pp. 206-237, jan.-jun. 2020 


\section{Considerações finais}

Ao revisitar as atividades das bandas de música do antigo município de Santo Amaro até sua incorporação à cidade de São Paulo em 1935, através de relatos e, sobretudo, por intermédio de fontes iconográficas, foi possivel perceber que essas corporações compartilharam o mérito com os diversos fenômenos sociais que, com - passar do tempo, perderam-se na memória oficial da cidade. Essas mesmas bandas testemunharam o modo singular de uma sociedade e seus segmentos sociais explicitados em diferentes momentos da comunidade, caracterizando-se também por seu aspecto coletivo e integrador a partir da construção de espaços de sociabilidade, afirmando uma determinada cultura e, consequentemente, sua identidade.

Apesar das transformações socioculturais decorrentes da anexação de Santo Amaro à capital paulista em 1935, este estudo observou a importância das bandas de música no que se refere à memória social e suas relações com a identidade de um povo.

No decorrer desta pesquisa, foram vários os indicativos sobre a importância das corporações musicais para os processos identitários da sociedade santo-amarense. Um deles faz referência à citação no trabalho de Dos Anjos (2016), quando se refere aos bens imateriais de Santo Amaro:

[...] As duas bandas de música atroavam os ares, com suas
marchas e dobrados perfeitamente ensaiados, enquanto o
povo aplaudia intensamente [...]. Foi festiva a comemoração,
como entusiásticas foram as palavras dos Drs. Raphael
Correia Sampaio, Carlos Samuel de Araújo e o vibrante
repertório das duas bandas presentes: "Treze de Maio" e
"16 de Julho" (REVISTA SANTO AMARO, 1961, p. 15 Apud
DOS ANJOS, 2016, p. 286 e 292).

No que diz respeito à herança da cultura musical de Santo Amaro, resistente e manifesta por intermédio do trabalho de bandas como a Corporação Musical Imaculada Conceição de Itapecerica da Serra e Banda Municipal de Embu das Artes, além de adaptações de obras do repertório sinfônico orquestral ou obras específicas das chamadas bandas sinfônicas, ressalta-se, a similaridade em uma espécie 
de continuidade do trabalho das bandas do antigo município de Santo Amaro em várias formas como, por exemplo, a manutenção do repertório tradicional escrito especificamente para bandas. No entanto, há também de se considerar que as semelhanças não se referem apenas pela opção no que diz respeito à manutenção do repertório tradicional desse modelo de banda, que é composto por marchas, dobrados e canções do imaginário popular. Essa inter-relação com as antigas bandas de Santo Amaro se fortalece também pela participação ativa nas festividades locais, como também nas habituais apresentações no coreto e nas alvoradas musicais ${ }^{13}$, além de oferecer um tom mais patriótico em inaugurações de equipamentos públicos, sobretudo, em cerimônias que ainda preservam a necessidade da execução ao vivo do Hino Nacional Brasileiro, antecedendo à fala oficial das autoridades.

\section{Referências}

CORREIO EMBUENSE. Banda Municipal. Embu das Artes; Edição de dezembro de 2014. pp. 4-5.

COSTA, Manuela Areias. Música e história: um estudo sobre as bandas de música civis e suas apropriações militares. In: Tempos Históricos v. 15, p. 240-260, $1^{\circ}$ semestre de 2011.

CUNHA, Rosemyriam. A prática musical coletiva. In: REVISTA BRASILEIRA DE MÚSICA, Rio de Janeiro, v. 26, n. 2, p. 345-365, Jul./Dez. 2013.

DOS ANJOS, Ana Christina C. Diálogos entre Patrimônio, Meio Ambiente e Aprendizagem Social: Uma experiência de Educação Patrimonial em pesquisa-ação no bairro paulistano de Santo Amaro. Tese (Doutorado) - Faculdade de Educação da Universidade de São Paulo, São Paulo, 2016.

FATORELLI. Carlos. Disponível em: http://carlosfatorelli27013. blogspot.com/20 13/04/corporacao-musical-de-santo-amaro.

13 "Alvorada musical" é o nome dado a qualquer música executada no começo da manhã com o objetivo de acordar as pessoas ou marcar o inicio das atividades. Apesar de ser tradição em algumas cidades do interior, essa prática é mais comum entre as tropas militares onde há um responsável pelos toques de corneta que transmitem ordens para grandes quantidades de soldados. Também é denominada de "matinada".

\section{5}

REV. TULHA, RIBEIRÃO PRETO, v. 6, n. I, pp. 206-237, jan.-jun. 2020 
html. Acesso em 30/01/2020. Corporação Musical de Santo Amaro. Publicado em 3 de abril de 2013.

GIARDINI, Mônica. A Banda Sinfônica Juvenil do Estado de São Paulo, sua organização, trajetoria e importância na formação de instrumentistas de sopros e de percussão. 2005. 184f. Dissertação (Mestrado em Musicologia) - Escola de Comunicação e Artes, da Universidade de São Paulo, 2005.

CIARDINI, Mônica. Entrevista de José de Carvalho Oliveira em 26/06/2020. São Paulo. Registro em vídeo.

CRANJA, Maria de Fátima. A banda: Som e Magia. Dissertação (Mestrado em Sistema de Comunicação) - Escola de Comunicação da Universidade Federal do Rio de Janeiro, 1984.

HARDMAN, Francisco Foot. Nem Pátria, nem Patrão! Memória Operária, cultura e literatura no Brasil. São Paulo: Editora Unesp, 2002.

OLIVEIRA, José de Carvalho. Historia da Educação Musical no Brasil. Brasília: Unyleya, 2019.

PERALTA, Inez Garbuio. Santo Amaro - um século de autonomia. $2^{\circ}$ edição. São Paulo: Campanygraf, 2017.

PERALTA, Inez Garbuio. Cemitério de Santo Amaro: Segredos ainda não revelados. São Paulo: Campanygraf, 2019.

REVISTA INTERLACOS. Corporação Musical Santamarense. São Paulo: Edição de março de 1951.

SANTIACO. Jorge P. Das práticas musicais aos arquivos vivos: Bandas brasileiras, literatura local e a cidade. REDIAL - Revista Europea de Información y Documentación sobre América Latina, Paris, v. 8-9, pp. 189-200, 1998.

SILVA, Juliana Soares da Costa. Praticas musicais, comunidade, localidade e velhice: um estudo etnografico sobre a corporação musical operária da Lapa. 2018. (142 p.). Dissertação (mestrado) Universidade Estadual de Campinas, Instituto de Artes, Campinas, SP.

\section{6}




\section{Sobre o autor}

Natural de Matias Olímpio, Piauí, José de Carvalho possui mestrado com pesquisa apoiada pela agência de fomento CAPES, sob orientação do Prof. Dr. Paulo de Tarso Salles, na área de Teoria e Análise pela Escola de Comunicação e Artes da Universidade de São Paulo - ECANUSP (2019). É formado em Licenciatura em Música pelo Centro Universitário Sant Anna e desde 2017 integra o corpo docente na referida instituição nos Cursos de Bacharelado e Licenciatura em Música. É editor assistente da Revista Música - ECA/USP - SP e, como pesquisador, pertence ao grupo de pesquisa PAMVILLA, Perspectivas Analíticas para a Música de Villa-Lobos. Possui trabalhos publicados no campo da Performance, Teoria, Análise Musical e Educação Musical. Como saxofonista dedica-se ao repertório brasileiro e contemporâneo. Atua como spalla e maestro assistente na Banda Municipal de Embu das Artes, SP, cidade a qual desenvolve também, sólido trabalho como coordenador na Escola Municipal de Música desde sua implantação no ano de 2014.

\section{Currículo Lattes: http://lattes.cnpa.br/2051026202284367 \\ ORCID: https://orcid.org/0000-0002-6803-6013}

Recebido em 20 /02/2020

Aprovado em 06/05/2020

\footnotetext{
I Agradecimento às pessoas que contribuíram para a realização desta pesquisa. Ao historiador Carlos Fatorelli, à maestrina Mônica Giardini, Secretaria de Cultura de Embu das Artes na pessoa de Lindomar Peixoto, ao maestro Hamilton Oliveira, ao ex-músico clarinetista da banda de Embu, e também ex-vereador de Embu das Artes, Gabriel Fidelis, ao Gian Marco Mayer de Aquino (Franguinho), maestrina Silvia Luisada, a todos os músicos da Banda Municipal de Embu das Artes representados por Heder Cardoso, Débora Simões, André de Oliveira Samogyi, Dr. Marcelo Lantyer, Suzana Chieme Miura e aos ex-músicos da banda de Embu, o jornalista e clarinetista Marcos Lemes e o artista plástico e saxofonista Camilo Filho.
} 